\title{
THE EVALUATIONS OF THE COLLEGE STUDENTS' PERCEPTIONS ON DISTANCE EDUCATION FROM THE POINT OF THE TECHNICAL AND EDUCATIONAL FACTORS
}

\author{
Assoc. Prof. Dr. Tolga GOK \\ Torbali Technical Vocational School of Higher Education \\ Dokuz Eylul University, TURKEY
}

\begin{abstract}
The purpose of the research was to investigate the college students' opinions about distance education courses. The distance education questionnaire (DEQ) was developed for evaluating the perceptions of the students. The DEQ was conducted on 66 college students enrolled in the compulsory courses. The DEQ consisted of 18 items and two factors covering the technical and educational factors in the light of statistical analyses. When the results of the research were generally evaluated, it could be said that the majority of the students were not pleased with the distance education courses from the point of the technical (connection, accessibility, etc.) and educational (interaction, communication, etc.) factors. Some implications were presented regarding the results.
\end{abstract}

Keywords: Distance education; distance learning; higher education; perception.

\section{INTRODUCTION}

Many teaching methods (inquiry-based learning, peer instruction, problem-based learning, brain-based learning, cooperative learning, and project-based learning, etc.) instead of traditional instruction have been developed so far by the researchers (Ebrahim, 2012; Author, 2014; Houff, Klinger, \& Coffman, 2013; Kogan \& Laursen, 2014; Puente \& Swagten, 2012). The common characteristic feature of those methods is the application of active learning. Students engage, explore, explain, extend, and evaluate the knowledge in and out of the classroom and instructor mentors to the students in the active learning. On the other hand, recently distance education has become popular as an alternative teaching method. The number of students enrolled in universities increased dramatically over the past years in worldwide (Bolliger \& Inan, 2012). Therefore, the institutions of higher education include universities, faculties, vocational schools of higher education, and institutes, etc. could address the demand in terms of campus, dormitory, building, instructors, laboratory, classroom, and time, etc. As a result of this, the institutions of higher education have started offering distance education courses/programs (Saba, 2011).

Many researchers (Anderson \& Ponti, 2014; Harvey, et al., 2014; Rovai, 2002; West, 2011, Young, et al., 2001; Young 2006) have examined the effects of distance education on teaching and learning in many different ways (the roles of students and instructors, the comparisons between face to face learning and distance learning, the cognitive perspectives of distance learning, and the effects of distance education on metacognitive strategies, etc.). 
These studies showed that distance learning differs from face to face learning in a number of ways covering communication, interaction, flexibility, and the roles of students and instructors, etc. It could be said that distance education is an effective teaching strategy according to traditional instruction pedagogically (Gaytan \& McEwen, 2007). Many studies are needed for determining the effects of distance learning and education; therefore distance education should be investigated in every aspect.

There are some advantages and disadvantages of the DE courses/programs as reported by the researchers (Bolliger \& Inan, 2012; Exter et al., 2009; Kanuka \& Jugdev, 2006; Motteram \& Forrester, 2005; Rovai, 2002; Shin, 2003; Tu \& McIsaac, 2002, West, 2011).

Some advantages of distance education courses/programs could be categorized as follows: a) the students could easily access online courses/programs regardless of location and time; b) the students could organize their study plans; c) the students could participate in an accelerated degree programs; d) the students could freely express the opinions and feelings in online courses; e) the students could freely share information with other students in distance learning courses/programs.

Some disadvantages of distance education courses/programs could be listed as follows: a) face-to-face personal interaction between students and instructor might be limited in online courses; b) lack of interaction amongst students enrolled in distance education courses/programs might be restricted; c) the students might encounter the issues of negative emotions (isolation, hopelessness, stress, anxiety, boredom, frustration, overload, and loneliness, etc.) technical problems (disconnectedness, network, and online communication, etc) and economical problems (the usage of old technologies and software, cost etc.); d) the instructor cannot integrate collaboration tools (discussion forum, chat rooms, etc.) into distance education courses/programs activities.

\section{The purpose of the research}

The purpose of the present study was to examine students' opinions about distance education courses. The opinions of the students were evaluated and collected with distance education questionnaire. The research question investigated was: Do the students prefer face to face learning or distance learning?

\section{METHOD}

\section{Participants}

This study was performed in a two-year college classroom. The participants selected in this study were 66 students from four different departments (i.e., Industrial Glass and Ceramics, Geotechnic, Drilling Technology, and Natural Building Stone Technology) at a state university in the Turkey. Of the participants, 24 students $(36.40 \%)$ were female while $42(63.60 \%)$ were male. Distance education questionnaire (DEQ) was given to students who completed compulsory courses which are suggested by council of higher education successfully. These courses cover History, Foreign Language, and Literature.

\section{Instrument and Procedures}

The DEQ was developed for this study by the researcher. The literature was examined to develop the basis for the distance education questionnaire (Barnard-Brak \& Shiu, 2010; Bolliger \& Inan, 2012; Chaney et al., 2007; Robert et al., 2005, Tu, 2002; Young 2006). 12 students were required to write an essay about their perceptions during distance learning. 
Also, several experts in distance education and six volunteer students from four different departments at the university were interviewed about distance education courses. The experts were instructed to

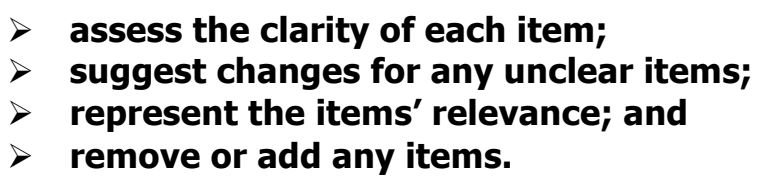

The items reported in the literature obtained from essays, interviews, and according to the evaluation report of the experts were categorized to construct the items of the questionnaire. The DEQ initially consisted of 52 positive and 6 negative statements. Respondents rated each item on a 5-point Likert scale, with the following scale anchors: 1=strongly disagree (SD), 2=disagree (D), 3=undecided (U), 4=agree (A), 5=strongly agree (SA). The validation and verification analyses were performed by giving the questionnaire to the students. Statistical analyses were performed with IBM SPSS Statistic 22.

The clarity of the items was pilot tested on 120 students not involved in the current study. These students' responses were submitted to statistical analyses to establish validity and reliability. The pilot test data were analyzed.

The statistical analysis indicated that the result of Bartlett's test of sphericity was 1294.77 for the questionnaire $(p<0.01)$. The questionnaire did not produce an identity matrix. Thus, multivariate normal distribution was accepted for factor analysis (Hair et al., 2009).

The value of 0.77 was obtained for Kaiser-Meyer-Olkin (KMO>0.60) from the principal component analysis. Rotation analysis was conducted with the principal component analysis and varimax method to identify the components. Two components having eigenvalues greater than 1.00 (Pett et al., 2003) were defined.

The validity was confirmed with the total variance percentage greater than $41 \%$ (Kline, 2005). Validity analysis enabled to include 18 items having the factor load of 0.50 in the questionnaire. The items with lower factor load $(\leq 0.50)$ were excluded. The factor distribution and factor load of these items are represented in Table 1. Total item load of 18 selected items changed from 0.886 to 0.519 .

The factors in the DEQ were defined as "Technical Factor and Educational Factor". The calculated variance percentage for the first factor "Technical Factor" including 8 items was $31.27 \%$.

The calculated variance percentages for the second factor "Educational Factor" was found as $\mathbf{4 1 . 1 6 \%}$ for 10 items. The first factor dealt with technical problems while the second factor dealt with educational issues.

The eigenvalues for the factors were 5.63 and 7.41, respectively. Two factors also accounted for $\mathbf{7 2 . 4 4 \%}$ of total variance. Cronbach's alpha value of the questionnaire was 0.90. The technical and educational factors' Cronbach's alpha values were found 0.81 and 0.89 , respectively. 
Table: 1

The Distribution of Factors and Factor Loads of the Items

\begin{tabular}{|c|c|c|c|}
\hline & Items & $\begin{array}{l}\text { Technical } \\
\text { Factor }\end{array}$ & $\begin{array}{l}\text { Educational } \\
\text { Factor }\end{array}$ \\
\hline 1 & $\begin{array}{l}\text { I think that the technical problems I encounter } \\
\text { should be solved as soon as possible. }\end{array}$ & 0.886 & \\
\hline 2 & I think that web-pages of the courses are functional. & 0.821 & \\
\hline 3 & $\begin{array}{l}\text { I think that the university provides the instructors } \\
\text { necessary and sufficient educational service } \\
\text { for the distance education courses. }\end{array}$ & 0.805 & \\
\hline 4 & $\begin{array}{l}\text { I could follow the distance education courses } \\
\text { indicated in the schedule. }\end{array}$ & 0.773 & \\
\hline 5 & $\begin{array}{l}\text { I can easily connect with } \\
\text { the distance education courses. }\end{array}$ & 0.756 & \\
\hline 6 & $\begin{array}{l}\text { I could return to the examination } \\
\text { questions if } I \text { have enough time. }\end{array}$ & 0.753 & \\
\hline 7 & $\begin{array}{l}\text { I think that it is better to give information and } \\
\text { tutorial about the system before starting the courses. }\end{array}$ & 0.705 & \\
\hline 8 & $\begin{array}{l}\text { I could easily take mid-term } \\
\text { and final examinations online. }\end{array}$ & 0.562 & \\
\hline 9 & $\begin{array}{l}\text { I think that distance education is } \\
\text { more suitable for numerical courses. }\end{array}$ & & 0.851 \\
\hline 10 & I could easily communicate with friends on the system. & & 0.847 \\
\hline 11 & $\begin{array}{l}\text { I think that distance education courses } \\
\text { are as effectively as the courses given in class. }\end{array}$ & & 0.795 \\
\hline 12 & $\begin{array}{l}\text { I think that distance education is more } \\
\text { suitable for language courses. }\end{array}$ & & 0.774 \\
\hline 13 & $\begin{array}{l}\text { I think that the contents of the mid-term and } \\
\text { final examinations are similar to the contents of the topics. }\end{array}$ & & 0.741 \\
\hline 14 & $\begin{array}{l}\text { I would like to continue } \\
\text { distance education courses in the future. }\end{array}$ & & 0.734 \\
\hline 15 & $\begin{array}{l}\text { I think that the presentations and } \\
\text { videos of the distance education } \\
\text { courses are understandable. }\end{array}$ & & 0.709 \\
\hline 16 & I could easily communicate with instructors. & & 0.645 \\
\hline 17 & I think that distance education courses are informative. & & 0.616 \\
\hline 18 & $\begin{array}{l}\text { I think that distance education courses } \\
\text { are more motivational than traditional courses. }\end{array}$ & & 0.519 \\
\hline
\end{tabular}

\section{RESULTS AND DISCUSSION}

The results of the distance education questionnaire were categorized into the technical and educational factors as follows.

\section{Technical Factor}

This factor dealt with technical problems of the distance education system which covers web-page of the courses, connection, accessibility, and usefulness, etc. The students' respondents for this factor were given in Table: 2. 
Table: 2

The Percentage Distributions of the Students Concerning Technical Factor

\begin{tabular}{|c|c|c|c|c|c|c|}
\hline & Items & SD & D & $\mathbf{U}$ & A & SA \\
\hline 1 & $\begin{array}{l}\text { I think that the technical problems } \\
\text { I encounter should be solved } \\
\text { as soon as possible. }\end{array}$ & $9.1 \%$ & $6.1 \%$ & $13.6 \%$ & $25.8 \%$ & $43.9 \%$ \\
\hline 2 & $\begin{array}{l}\text { I think that web-pages of } \\
\text { he courses are functional. }\end{array}$ & $40.9 \%$ & $6.1 \%$ & $24.2 \%$ & $22.7 \%$ & $6.1 \%$ \\
\hline 3 & $\begin{array}{l}\text { I think that the university provides the } \\
\text { instructors necessary and sufficient } \\
\text { educational service for the distance } \\
\text { education courses. }\end{array}$ & $42.4 \%$ & $15.2 \%$ & $16.7 \%$ & $18.2 \%$ & $7.6 \%$ \\
\hline 4 & $\begin{array}{l}\text { I could follow the distance education } \\
\text { courses indicated in the schedule. }\end{array}$ & $45.5 \%$ & $10.6 \%$ & $13.6 \%$ & $15.2 \%$ & $10.6 \%$ \\
\hline 5 & $\begin{array}{l}\text { I can easily connect with the distance } \\
\text { education courses. }\end{array}$ & $43.9 \%$ & $18.2 \%$ & $12.1 \%$ & $13.6 \%$ & $10.6 \%$ \\
\hline 6 & $\begin{array}{l}\text { I could return to the examination } \\
\text { questions if I have enough time. }\end{array}$ & $54.5 \%$ & $12.1 \%$ & $15.2 \%$ & $12.1 \%$ & $6.1 \%$ \\
\hline 7 & $\begin{array}{l}\text { I think that it is better to give } \\
\text { information and tutorial about the } \\
\text { system before starting the courses. }\end{array}$ & $4.5 \%$ & $7.6 \%$ & $19.7 \%$ & $27.3 \%$ & $40.9 \%$ \\
\hline 8 & $\begin{array}{l}\text { I could easily take mid-term and final } \\
\text { examinations online. }\end{array}$ & $48.5 \%$ & $12.1 \%$ & $15.2 \%$ & $15.2 \%$ & $7.6 \%$ \\
\hline
\end{tabular}

$770 \%$ of the students would like the technical problems they encounter to be solved as soon as possible.

$>47 \%$ of the students think that web-pages of the courses are not functional.

$>58 \%$ of the students think that the university does not provide the instructors necessary and sufficient educational service for the distance education courses.

$>56 \%$ of the students do not want to follow the distance education courses indicated in the schedule.

$>62 \%$ of the students do not easily connect with the distance education courses.

$>67 \%$ of the students could not return the examination questions if they have enough time.

$>68 \%$ of the students think that it is better to give information about the system and apply it before starting the distance education courses.

$>61 \%$ of the students could not easily take mid-term and final examinations online.

\section{Educational Factor}

This factor dealt with educational issues which include communication and interaction between the instructor and the students, motivations and perceptions of the students, etc.

The students' respondents for this factor were given in Table: 3. 
Table: 3

The Percentage Distributions of the Students Concerning Educational Factor

\begin{tabular}{|c|c|c|c|c|c|c|}
\hline & Items & SD & D & $\mathbf{U}$ & A & SA \\
\hline 1 & $\begin{array}{l}\text { I think that distance education } \\
\text { is more suitable for numerical } \\
\text { courses. }\end{array}$ & $45.5 \%$ & $16.7 \%$ & $12.1 \%$ & $10.6 \%$ & $13.6 \%$ \\
\hline 2 & $\begin{array}{l}\text { I could easily communicate } \\
\text { with friends on the system. }\end{array}$ & $42.4 \%$ & $13.6 \%$ & $18.2 \%$ & $12.1 \%$ & $13.6 \%$ \\
\hline 3 & $\begin{array}{l}\text { I think that distance education } \\
\text { courses are as effectively as } \\
\text { the courses given in class. }\end{array}$ & $51.5 \%$ & $10.6 \%$ & $10.6 \%$ & $6.1 \%$ & $19.7 \%$ \\
\hline 4 & $\begin{array}{l}\text { I think that distance education } \\
\text { is more suitable for language } \\
\text { courses. }\end{array}$ & $47.0 \%$ & $10.6 \%$ & $15.2 \%$ & $9.1 \%$ & $18.2 \%$ \\
\hline 5 & $\begin{array}{l}\text { I think that the contents } \\
\text { of the mid-term and final } \\
\text { examinations are similar } \\
\text { to the contents of the topics. }\end{array}$ & $22.7 \%$ & $7.6 \%$ & $43.9 \%$ & $18.2 \%$ & $6.1 \%$ \\
\hline 6 & $\begin{array}{l}\text { I would like to continue distance } \\
\text { education courses in the future. }\end{array}$ & $48.5 \%$ & $12.1 \%$ & $15.2 \%$ & $6.1 \%$ & $18.2 \%$ \\
\hline 7 & $\begin{array}{l}\text { I think that the presentations and } \\
\text { videos of the distance education } \\
\text { courses are understandable. }\end{array}$ & $40.9 \%$ & $19.7 \%$ & $13.6 \%$ & $13.6 \%$ & $12.1 \%$ \\
\hline 8 & $\begin{array}{l}\text { I could easily communicate } \\
\text { with instructors. }\end{array}$ & $51.5 \%$ & $13.6 \%$ & $19.7 \%$ & $7.6 \%$ & $7.6 \%$ \\
\hline 9 & $\begin{array}{l}\text { I think that distance education } \\
\text { courses are informative. }\end{array}$ & $48.5 \%$ & $12.1 \%$ & $12.1 \%$ & $12.1 \%$ & $15.2 \%$ \\
\hline 10 & $\begin{array}{l}\text { I think that distance education } \\
\text { courses are more motivational } \\
\text { than traditional courses. }\end{array}$ & $42.4 \%$ & $13.6 \%$ & $16.7 \%$ & $9.1 \%$ & $18.2 \%$ \\
\hline
\end{tabular}

$60 \%$ of the students think that distance education is not suitable for numerical and language courses.

$>$ Approximately $60 \%$ of the students think that they could not easily communicate with friends and instructors on the system.

$>62 \%$ of the students think that the distance education courses are not as effectively as the courses given in class.

$>44 \%$ of the students doubt that the contents of the mid-term and final examinations are similar to the contents of the topics.

$>61 \%$ of the students do not want to take and continue different distance education courses in the future.

$>61 \%$ of the students think that the presentations and videos of the distance education courses are not understandable.

$>61 \%$ of the students think that the distance education courses are not informative.

$>56 \%$ of the students think that the distance education courses are not more motivational than traditional courses. 


\section{CONCLUSION}

The purpose of this study was to assess the quality of the distance education courses through evaluation of the students' opinions. The instrument, called the DEQ (Distance Education Questionnaire) was developed for this study. When the students' perceptions were generally evaluated, the students were not pleased with distance education courses. Some results according to the students' perceptions were presented in terms of the educational and technical factors as follows:

$>$ Distance education is not suitable for language and numerical courses. The students do not know how to learn and study the distance educations courses in this system.

$>$ Distance education does not sufficiently provide the communication and interaction between the instructor and the students. The students usually prefer to learn by asking relevant questions or topics.

$>$ The students have great difficulty learning the topics in the distance education courses therefore these courses are not adequately effective in motivate the students.

$>$ The instructors do not usually follow the syllabus in the distance education courses. Therefore the students could encounter some problems. As a result of this, in the mid-term and final examinations the students would be asked the questions concerning the topics which the students did not learn or know

$>$ Many of the students do not want to choose and follow new distance education course in the next term.

$>$ Most of the students have great difficulty in connecting the courses' webpages and they could not easily take mid-term, quizzes, and final examination. Therefore they think that web-pages of the courses are not sufficient from the technical aspect.

$>$ Majority of the students could not return to the examination questions even if they have enough time. The system does not allow them to check the examination questions during the examination. This situation might negatively influence the performance of the students.

$>$ The students and instructors had not been given any training concerning how to use online courses at the beginning.

\section{IMPLICATIONS}

When the results of the research were generally evaluated and interpreted in terms of the educational and technical factors, some implications might be offered as follows: The learning strategies (cognitive, metacognitive, and resource management strategies) in regard to distance education courses or programs should be taught to the students.

The office hours should be arranged to provide communication and interaction between the students and the instructor. Thus the students can ask the questions, they can learn the concepts and fundamental principles regarding the topics. From this aspect, one of the disadvantages in online courses could be eliminated. Besides, the hybrid model which consists of distance education and face to face education for active learning classroom environment could be used in the online courses. The students can easily make contact with class friends and instructor.

To enhance the motivation of the students in distance learning, the students should be given some responsibilities (projects, paper-based homework, and presentation, etc.) 
providing their learning. Besides, live (not prerecorded) distance education courses should be designed instead of videos and presentations. By this means the students would like to attend and follow the courses.

The indicated syllabus should be followed and applied in online courses. The contents of examinations should be similar to the contents of the topics. The students should not be laid heavy burdens in distance education courses. The instructors should explain each topic as presented in the schedule. They should remark the students' achievement level and background in online courses.

Web-pages of the courses should be user friendly. Students should easily connect the online courses and examinations regardless of time and place. They should go back and forth the examination questions during the examination period. Technical problems the students encounter should be solved as soon as possible. Besides, the students and instructors should be trained concerning distance education courses and they should practice on the system at the beginning.

To enhance the quality of distance education courses or programs, the economical, technical, and educational problems should be initially eliminated by the institutions of higher education, and then the instructors should be adequately prepared with the teaching strategies and techniques required to teach and conduct effective distance education courses/programs. Finally, the students should need to take their own responsibility for distance learning.

\section{BIODATA and CONTACT ADDRESSES of the AUTHOR}

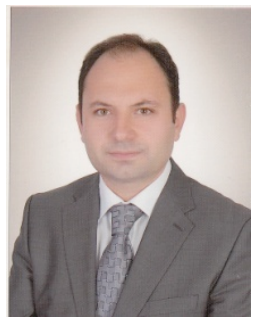

Assoc. Prof. Dr. Tolga GOK was born at Izmir, Turkey in 1976. He had his bachelor (1999) and Ph. D. (2006) degree from the Department of Physics Education, Dokuz Eylul University. He studied as a post-doctoral (20082010) fellow at the Department of Physics in Colorado School of Mines, US. His research subjects are physics education and educational technology. He has been working as an instructor at Dokuz Eylul University, Izmir, Turkey since 2002.

Assoc. Prof. Dr. Tolga GOK

Torbali Technical Vocational School of Higher Education

Dokuz Eylul University

Izmir 35860, Turkey

Phone: +90 2328531820

Fax: +902328531606

Email: tolga.gok@deu.edu.tr

\section{REFERENCES}

Anderson, R., \& Ponti, M. (2014). Participatory pedagogy in an open educational course: Challenges and opportunities. Distance Education, 35(2), 234-249.

Barnard-Brak, L., \& Shiu, W. (2010). Classroom community scale in the blended learning environment: A psychometric review. International Journal on E-Learning, 9(3), 303-311.

Bolliger, D. U., \& Inan, F. A. (2012). Development and validation of the online student connectedness survey (OSCS). The International Review of Research in Open and Distance Learning, 13(3), 41-65. 
Chaney, B. H., Eddy, J. M., Dorman, M., Glessner, L., Green, B. L., \& Lara-Alecio, R. (2007). Development of an instrument to assess student opinions of the quality of distance education courses. American Journal of Distance Education, 21(3), 145-164.

Ebrahim, A. (2012). The effect of cooperative learning strategies on elementary students' science achievement and social skills in Kuwait. International Journal of Science and Mathematics Education, 10(2), 293-314.

Exter, M. E., Korkmaz, N., Harlin, N. M., \& Bichelmeyer, B. A. (2009). Sense of community within a fully online program: Perspective of graduate students. The Quarterly Review of Distance Education, 10(2), 177-194.

Gaytan, J., \& McEwen, B. C. (2007). Effective online instructional and assessment strategies. American Journal of Distance Education, 21(3), 117-132.

Hair, J. F., Black, W. C., Babin, B. J., Anderson, R. E. \& Tatham, R. L. (2009). Multivariate data analysis (7th edn). Upper Saddle River, NJ: Pearson Education.

Harvey, D., Greer, D., Basham, J., \& Hu, B. (2014). From the student perspective: Experiences of middle and high school students in online learning, American Journal of Distance Education, 28(1), 14-26.

Houff, S., Klinger, M. B., \& Coffman, T. (2013). Using brain-based learning strategies in the classroom. In. Jan Herrington et al. (Eds.), Proceedings of World Conference on Educational Multimedia, Hypermedia and Telecommunications. 2060-2069. Chesapeake, VA: AACE.

Kanuka, H., \& Jugdev, K. (2006). Distance education MBA students: An investigation into the use of an orientation course to address academic and social integration issues. Open Learning, 21(2), 153-166.

Kline, R. B. (2005). Principles and practice of structural equation modeling (2nd ed.). New York: Guilford.

Kogan, M., \& Laursen, S. L. (2014). Assessing long-term effects of inquiry-based learning: A case study from college mathematics. Innovative Higher Education, 39(3), 183-199.

Motteram, G., \& Forrester, G. (2005). Becoming an online distance learner: What can be learned from students' experiences of induction to distance programmes. Distance Education, 26(3), 281-298.

Pett, M., Lackey, N., \& Sullivan, J. (2003). Making sense of factor analysis. Thousand Oaks: Sage Publications, Inc.

Puente, S. M. G., \& Swagten, H. J. M. (2012). Designing learning environments to teach interactive quantum physics. European Journal of Engineering Education, 37(5), 448-547.

Roberts, T. G., Irani, T. A., Telg, R. W., \& Lundy, L. K. (2005). The development of an instrument to evaluate distance education courses using student attitudes. American Journal of Distance Education, 19(1), 51-64.

Rovai, A. P. (2002). Sense of community, perceived cognitive learning, and persistence in asynchronous learning networks. The Internet and Higher Education, 5, 319- 332. 
Saba, F. (2011). Distance education in the United States: Past, present, future. Educational Technology, November-December, 11-18.

Shin, N. (2003). Transactional presence as a critical predictor of success in distance learning. Distance Education, 24(1), 69-86.

Tu, C. (2002). The measurement of social presence in an online learning environment. International Journal on E-Learning, 1(2), 34-45.

Tu, C., \& McIsaac, M. (2002). The relationship between social presence and interaction in online classes. American Journal of Distance Education, 16(3), 131-150.

West, R. E. (2011). Insights from research on distance education learners, learning, and learner support. American Journal of Distance Learning, 25, 135-151.

Young, S., Cantrell, P., \& Shaw, D. (2001). Online instruction: New roles for teachers and students. Academic Exchange Quarterly, 5(4), 11-16.

Young, S. (2006). Student views of effective online teaching in higher education. American Journal of Distance Education, 20(2), 65-77. 